\title{
Stále tristní stav organizace znalecké činnosti v ČR
}

\section{Still Poor State of Organization of Expert Activities in the Czech Republic}

\author{
Albert Bradáč ${ }^{*}$ \\ Vysoké učeni technické v Brně, Ústav soudniho inženýrství, Brno
}

\begin{abstract}
Abstrakt
V př́spěvku je analyzován stav organizace znalecké činnosti v podmínkách České republiky, zejména ve vztahu k oborům technickým ekonomickým; analyzována je také situace znaleckých ústavů. Demonstrován je dlouhodobý pokles zájmu o znaleckou činnost jak ze strany odborníků - fyzických osob, tak u znaleckých ústavů, zejména vysokých škol a výzkumných institucí. Je proveden rozbor problematiky odměňování znalců a znaleckých ústavů při podávání znaleckých posudků pro orgány veřejné moci při dlouhodobě stagnujících sazbách hodinové odměny.
\end{abstract}

Klíčová slova: znalec, znalecký ústav, Ministerstvo spravedlnosti, rízeni znalecké činnosti, odměňování znalecké činnosti.

Problematika organizace znalecké činnosti, zejména ve vztahu k orgánům veřejné moci, se již stala evergreenem, nicméně autor považuje vzhledem $\mathrm{k}$ současnému projednávání nového zákona o znalcích za vhodné aktualizovat některé údaje z předešlých př́spěvků. Předchozí stav byl publikován ${ }^{1)}$; obdobná analýza byla zaslána i paní prof. JUDr. Heleně Válkové, CSc., poslankyni PS PČR a člence mj. podvýboru pro justici a soudní samosprávu. Zaslána byla v březnu 2018 cestou datové schránky také novému předsedovi vlády Ing. Andreji Babišovi; lze jen dodat, že pan předseda vlády na zaslaný rozbor nijak nereagoval, na rozdíl od předešlého premiéra Mgr. Bohuslava Sobotky.

V prvé řadě se jedná o permanentně klesající počet znalců a znaleckých ústavů (tab. 1-4, obr. 1-3).

Dalším zajímavým údajem je procento počtu posudků, jež znalci zpracovávají pro orgány veřejné moci, pro občany a pro ostatní

\footnotetext{
1) Bradáč, A., Vémola, A., Bradáč, A. Ekonomické a další problémy výkonu znalecké činnosti v ČR. Soudní inženýrství, 2017, 28(2-3), s. 156-165. Bradáč, A. K současnému stavu znalecké činnosti v ČR. Soudní inženýrství, 2017, 28(2-3), s. 68-76.
}

\begin{abstract}
The contribution analyzes the state of organization and implementation of expert activities in the conditions of the Czech Republic, especially in relation to the fields of technical economics; the situation of expert institutions is also being analyzed. Demonstrated is the long-term decline of interest in expert activity both by experts - natural persons and by expert institutions, especially universities and research institutions. An analysis of the issue of the remuneration of experts and expert bodies in the submission of expert opinions to public authorities at long-term staggered hourly rewards is done.
\end{abstract}

Keywords: expert, expert institute, Ministry of Justice, management of expert activity, remuneration of expert activity.

zadavatele. Data pro porovnání jsou z roku 1999 (tab. 5, obr. 4) a v další části ze statistiky Ministerstva spravedlnosti 2016 (tab. 6, obr. 5).

Jednou z prríčin poklesu zájmu o činnost znalců jsou jistě odměny znalců za posudky pro orgány veřejné moci při sazbách z vyhlášky č. 37/1967 Sb. v aktuálním znění z roku 2002 ve výši 100 až 350 Kč za hodinu. Sazba se na první pohled jeví jako dosti vysoká, je však třeba si uvědomit, co všechno je třeba z této odměny hradit, pokud ji porovnáme s OSVČ, resp. co všechno musí hradit z přijaté odměny zaměstnavatel, pokud se jedná o posudek znaleckého ústavu. Jak uvedeno výše, podrobný rozbor byl proveden již drríve; po odpočtu nákladů, jež musí nést $\mathrm{z}$ odměny znalec, resp. znalecký ústav, $\mathrm{v}$ protikladu s hrubou mzdou zaměstnanců $\mathrm{v}$ národním hospodářství, kdy náklady nese zaměstnavatel. Je zřejmé, že i při nejvyšší sazbě na odměnu znalce (resp. zpracovatele znaleckého posudku ústavu) zbývá sotva částka, podobná minimální mzdě, při nižších sazbách je výsledek dokonce záporný (viz tab. 7, obr. 6).

A ani nyní navrhované sazby po odečtení nákladů negarantují přiměřenou částku. 
Občas se v médiích objevují pochybnosti o morální úrovni znalců. Podle statistiky Ministerstva spravedlnosti za rok 2015 bylo znalcům uloženo:

- 34 pokut za přestupky, tj, z celkového počtu znalců $0,34 \%$,

- 5 výstrah, tj. 0,05\%.

Za trestný čin podle $§ 346$ trestního zákoníku (Křivá výpověd' a nepravdivý znalecký posudek) bývá ročně odsouzeno okolo 180 osob, převážně ovšem za křivou výpověd’.

Otázkou zůstává také vysoký věk znalců - fyzických osob. Z grafu na obr. 8 je zřejmé vysoké stář́ znalců - analytiků silničních nehod, členů EVU - Evropské společnosti pro výzkum a analýzu nehod, z.s. Obdobné hodnoty vykazuje členská základna Asociace znalců a odhadců ČR, z.s. resp. České komory odhadců majetku, z.s. Data o stáří všech znalců ČR autorovi bohužel Ministerstvo spravedlnosti neposkytlo, přestože jiná osobní data znalců nevyžadoval - jen anonymně stáří.

V současné době se v Parlamentu projednává (již pokolikáté!) pokus o nový zákon o znalcích (snad se konečně dočkáme uznání titulu „soudní znalec“). Zůstává otázkou, zda nový zákon negativní trend v úbytku počtu znalců a znaleckých ústavů zastaví a přinese formální ozdravení organizace znalecké činnosti, nebo jen zvýšení formalismu a byrokratické zátěže.

\section{ZÁVĚREM}

Dne 20. 11. 2018 rozhodla vláda zvýšit minimální mzdu od 1. ledna 2019 z částky 12200 Kč na 13350 Kč měsíčně. Po přepočtu výše uvedených hodnot dojdeme k tomu, že při stávající maximální sazbě znalečného za posudky pro orgány veřejné moci $350 \mathrm{Kč} / \mathrm{h}$ zbývá znaleckému ústavu (u znalců jednotlivých obdobně) po odečtení povinných odvodů a reálných provozních nákladů na mzdy špičkových odborníků jen 10415 Kč (viz obr. 7), tj.

$$
\frac{10415 \mathrm{Kč}}{13350 \mathrm{Kc \check {c }}} \cdot 100 \%=78 \% \text { minimální mzdy, }
$$

resp. při průměrné mzdě k 20. 11. 2018 ve výši 31851 Kč jen

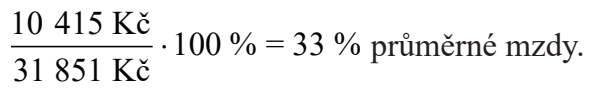

Tab. 1 Vývoj počtu znaleckých ústavů od roku 2007 do 09/ 2018.

Tab. 1 Development of the number of expert institutes from 2007 to 09/2018.

\begin{tabular}{lccccccccccccc}
\hline Druh ústavu / rok & $\mathbf{2 0 0 7}$ & $\mathbf{2 0 0 9}$ & $\mathbf{2 0 1 0}$ & $\mathbf{2 0 1 1}$ & $\mathbf{2 0 1 2}$ & $\mathbf{2 0 1 3}$ & $\mathbf{2 0 1 4}$ & $\mathbf{2 0 1 5}$ & $\mathbf{2 0 1 6}$ & $\mathbf{2 0 1 7}$ & $\mathbf{2 0 1 8}$ & Změna počet & Změna procent \\
\hline $\begin{array}{l}\text { Ústavy I. oddílu } \\
\begin{array}{l}\text { (ústavy specializované } \\
\text { na znaleckou činnost) }\end{array}\end{array}$ & 151 & 157 & 163 & 158 & 156 & 127 & 125 & 130 & 135 & 140 & 142 & -9 & -6 \\
\hline $\begin{array}{l}\text { Ústavy II. oddílu } \\
\begin{array}{l}\text { (vědecké ústavy, } \\
\text { vysoké školy ap.) }\end{array}\end{array}$ & 282 & 288 & 279 & 256 & 228 & 190 & 188 & 185 & 182 & 181 & 174 & -108 & -38 \\
\hline
\end{tabular}

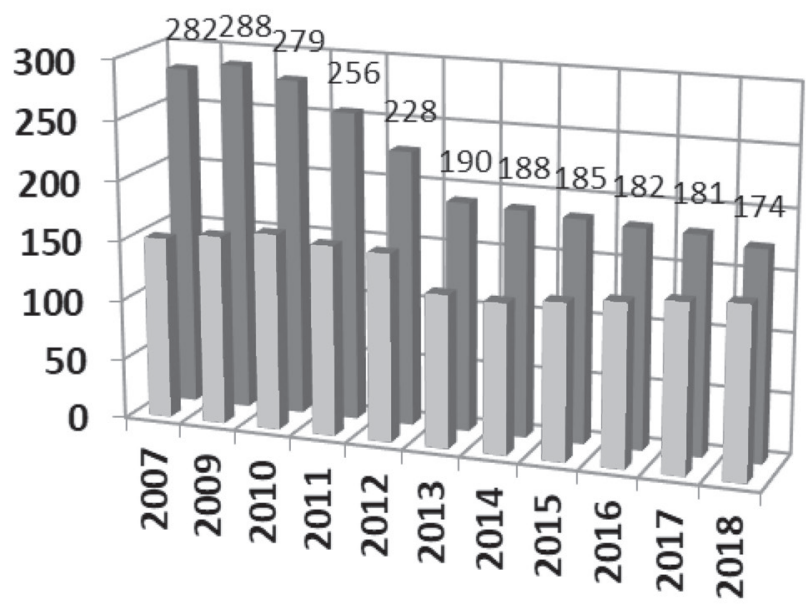

Ústavy II. oddílu (vědecké
ústavy, vysoké školy ap.)

Ústavy I. oddílu (ústavy specializované na znaleckou činnost)

Obr. 1 Vývoj počtu znaleckých ústavio od roku 2007 do 09/ 2018.

Fig. 1 Development of the number of expert institutes from 2007 to 09/2018. 
Tab. 2 Vývoj počtu znaleckých ústavů I. oddilu od roku 2007 do 09/2018 v některých oborech.

Tab. 2 Development of the number of expert departments of the first division from 2007 to 09/2018 in some fields.

\begin{tabular}{|c|c|c|c|c|c|c|c|c|c|c|}
\hline \multirow{2}{*}{ Obor } & \multicolumn{10}{|c|}{ Znalecké ústavy I. oddíl } \\
\hline & 2007 & 2009 & 2010 & 2011 & 2012 & 2013 & 2016 & 2018 & Změna od r. 2007 & Změna od r. 2007 (\%) \\
\hline Doprava & 11 & 10 & 10 & 10 & 7 & 6 & 7 & 8 & -3 & -27 \\
\hline Chemie & 2 & 2 & 2 & 1 & 1 & 0 & 0 & 0 & -2 & -100 \\
\hline Kybernetika & 2 & 2 & 3 & 3 & 3 & 4 & 5 & 8 & 6 & 300 \\
\hline Písmoznalectví & 3 & 2 & 2 & 1 & 1 & 0 & 0 & 0 & -3 & -100 \\
\hline Projektování & 3 & 3 & 3 & 4 & 4 & 3 & 3 & 3 & 0 & 0 \\
\hline Strojírenství & 14 & 15 & 15 & 15 & 12 & 7 & 8 & 11 & -3 & -21 \\
\hline Školství & 1 & 2 & 2 & 2 & 2 & 0 & 1 & 2 & 1 & 100 \\
\hline Školství a kultura & 1 & 2 & 2 & 2 & 2 & 0 & 1 & 2 & 1 & 100 \\
\hline Zemědělství & 3 & 3 & 3 & 2 & 1 & 0 & 1 & 1 & -2 & -67 \\
\hline
\end{tabular}

\section{Znalecké ústavy II. oddílu (vysoké školy, vědecké ústavy)}

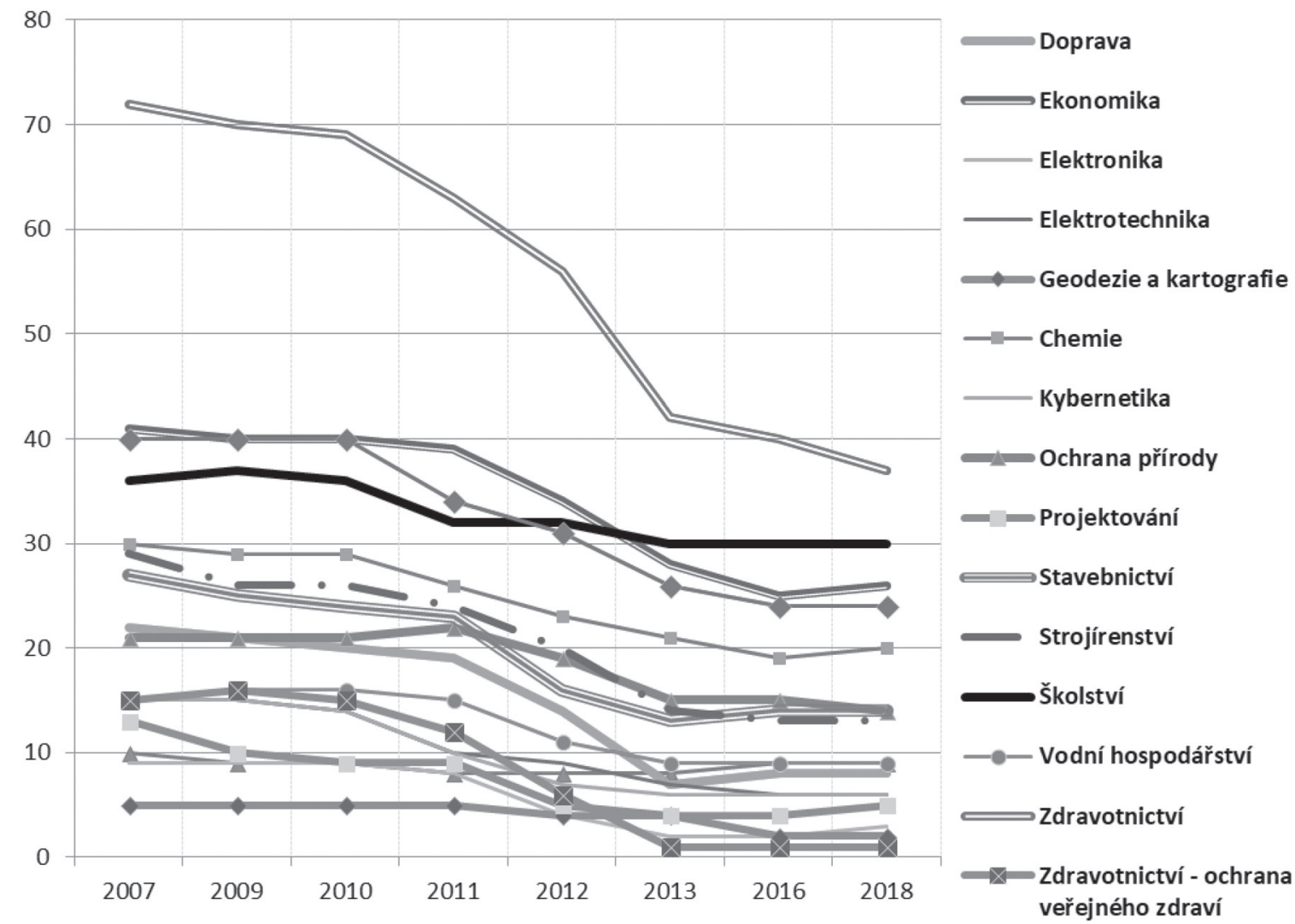

Obr. 2 Vývoj počtu znaleckých ústavì II. oddílu od roku 2007 do 09/ 2018 v některých oborech.

Fig. 2 Development of the number of expert institutions II. from 2007 to 09/2018 in some fields. 
Tab. 3 Vývoj počtu znaleckých ústavů II. oddílu od roku 2007 do 09/ 2018 v některých oborech.

Tab. 3 Development of the number of expert institutions II. from 2007 to 09/2018 in some fields.

\begin{tabular}{|c|c|c|c|c|c|c|c|c|c|c|}
\hline \multirow{2}{*}{ Obor } & \multicolumn{10}{|c|}{ Znalecké ústavy II. oddíl (VŠ a vědecké ústavy) } \\
\hline & 2007 & 2009 & 2010 & 2011 & 2012 & 2013 & 2016 & 2018 & Změna od r. 2001 & Změna od r. $2007(\%)$ \\
\hline Čistota ovzduší & 10 & 9 & 9 & 8 & 8 & 8 & 9 & 8 & -1 & -10 \\
\hline Doprava & 22 & 21 & 20 & 19 & 14 & 7 & 8 & 8 & -14 & -64 \\
\hline Ekonomika & 41 & 40 & 40 & 39 & 34 & 28 & 25 & 26 & -15 & -37 \\
\hline Elektronika & 9 & 9 & 9 & 8 & 4 & 2 & 2 & 3 & -6 & -67 \\
\hline Elektrotechnika & 15 & 15 & 14 & 10 & 9 & 7 & 6 & 6 & -9 & -60 \\
\hline Geodezie a kartografie & 5 & 5 & 5 & 5 & 4 & 4 & 2 & 2 & -3 & -60 \\
\hline Chemie & 30 & 29 & 29 & 26 & 23 & 21 & 19 & 20 & -10 & -33 \\
\hline Kybernetika & 15 & 15 & 14 & 10 & 7 & 6 & 6 & 6 & -9 & -60 \\
\hline Ochrana přírody & 21 & 21 & 21 & 22 & 19 & 15 & 15 & 14 & -7 & -33 \\
\hline Projektování & 13 & 10 & 9 & 9 & 5 & 4 & 4 & 5 & -8 & -62 \\
\hline Stavebnictví & 27 & 25 & 24 & 23 & 16 & 13 & 14 & 15 & -13 & -48 \\
\hline Strojírenství & 29 & 26 & 26 & 24 & 20 & 14 & 13 & 12 & -16 & -55 \\
\hline Školství & 36 & 37 & 36 & 32 & 32 & 30 & 30 & 30 & -6 & -17 \\
\hline Vodní hospodářství & 15 & 16 & 16 & 15 & 11 & 9 & 9 & 9 & -6 & -40 \\
\hline Zdravotnictví & 72 & 70 & 69 & 63 & 56 & 42 & 40 & 36 & -35 & -49 \\
\hline $\begin{array}{l}\text { Zdravotnictví - ochrana } \\
\text { veřejného zdraví }\end{array}$ & 15 & 16 & 15 & 12 & 6 & 1 & 1 & 1 & -14 & -93 \\
\hline Zemědělství & 40 & 40 & 40 & 34 & 31 & 26 & 24 & 24 & -16 & -40 \\
\hline
\end{tabular}

Tab. 4 Vývoj počtu znalcü - fyzických osob od roku 2007 do 09/ 2018.

Tab. 4 Development of the number of experts - natural persons from 2007 to 09/2018.

\begin{tabular}{lccccccccccc}
\hline \multicolumn{10}{c}{ Počet znalců - fyzických osob v ČR } \\
\hline Rok & $\mathbf{2 0 0 7}$ & $\mathbf{2 0 0 8}$ & $\mathbf{2 0 0 9}$ & $\mathbf{2 0 1 0}$ & $\mathbf{2 0 1 1}$ & $\mathbf{2 0 1 2}$ & $\mathbf{2 0 1 3}$ & $\mathbf{2 0 1 5}$ & $\mathbf{2 0 1 6}$ & $\mathbf{2 0 1 7}$ & $\mathbf{2 0 1 8}$ \\
\hline Celkem znalců (fyzických osob) & 10992 & 10791 & 10627 & 10377 & 10158 & 9978 & 9865 & 9620 & 9220 & 8965 & 8634 \\
V procentech roku 2007 & 100 & 98 & 97 & 94 & 92 & 91 & 90 & 88 & 84 & 82 & 79 \\
\hline
\end{tabular}

\section{Celkem znalců (fyzických osob)}

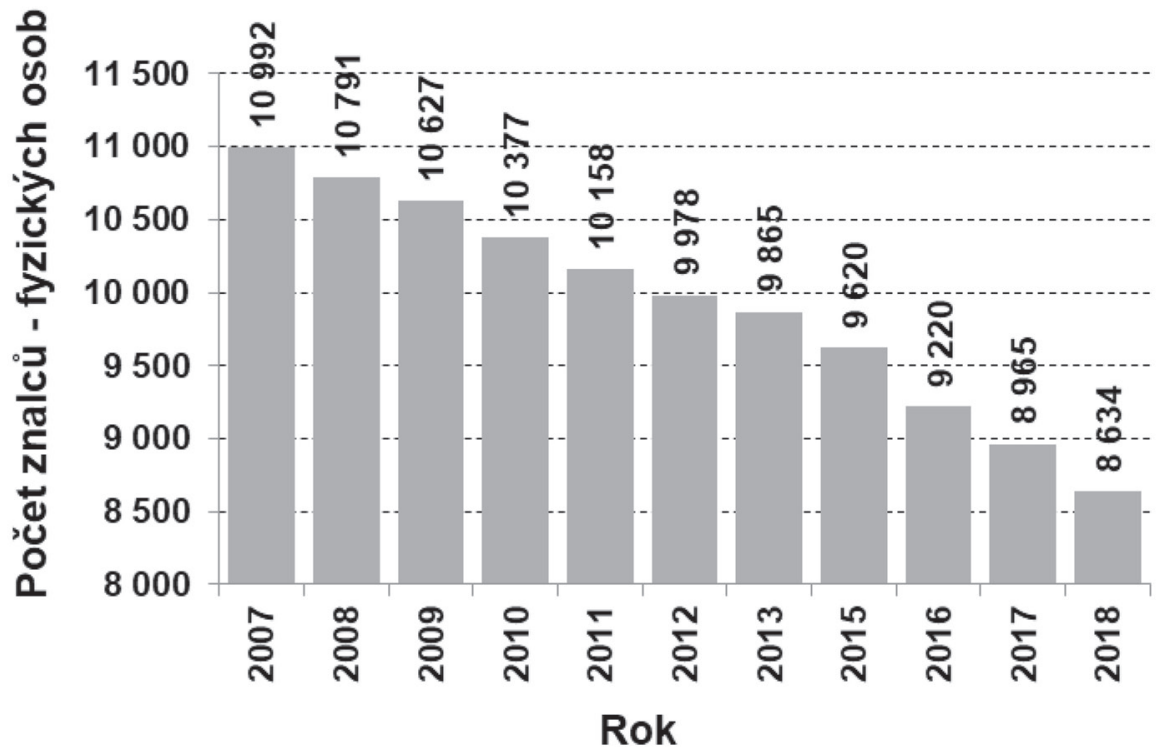

Obr. 3 Vývoj počtu znalců-fyzických osob od roku 2007 do 09/2018.

Fig. 3 Development of the number of experts from 2007 to 09/2018. 
Tab. 5 Počty znaleckých posudků určených pro orgány veřejné moci po přepočtu celkem (1999).

Tab. 5 Numbers of expert opinions intended for public authorities after total conversion (1999).

\begin{tabular}{|c|c|c|c|c|c|c|}
\hline \multirow[b]{2}{*}{ Obor } & \multicolumn{3}{|c|}{ Celkem posudků pro } & \multicolumn{3}{|c|}{ Celkem \% pro } \\
\hline & $\begin{array}{l}\text { Orgány veřejné } \\
\text { moci přímo } \\
\text { a nepřímo }\end{array}$ & $\begin{array}{c}\text { Práv. osoby } \\
\text { a OSVČ }\end{array}$ & Občany & $\begin{array}{l}\text { Orgány veřejné } \\
\text { moci přímo } \\
\text { a nepřímo }\end{array}$ & $\begin{array}{c}\text { Práv. osoby } \\
\text { a OSVČ }\end{array}$ & Občany \\
\hline Psychiatrie & 25111 & 27 & 58 & 99,7 & 0,1 & 0,2 \\
\hline Doprava silniční a městská & 2656 & 81 & 53 & 95,2 & 2,9 & 1,9 \\
\hline Oceňování věcí movitých & 26818 & 3176 & 3185 & 80,8 & 9,6 & 9,6 \\
\hline Oceňování nemovitostí & 203820 & 38719 & 50816 & 69,5 & 13,2 & 17,3 \\
\hline Oceňování motorových vozidel & 30023 & 17491 & 5947 & 56,2 & 32,7 & 11,1 \\
\hline Ostatní obory & 40732 & 6418 & 6491 & 75,9 & 12,0 & 12,1 \\
\hline Celkem & 329161 & 65912 & 66550 & 71,3 & 14,3 & 14,4 \\
\hline
\end{tabular}

Procentuální zastoupení znalecké činnosti pro orgány veřejné moci, právnické osoby vč. OSVČ a občany (1999)

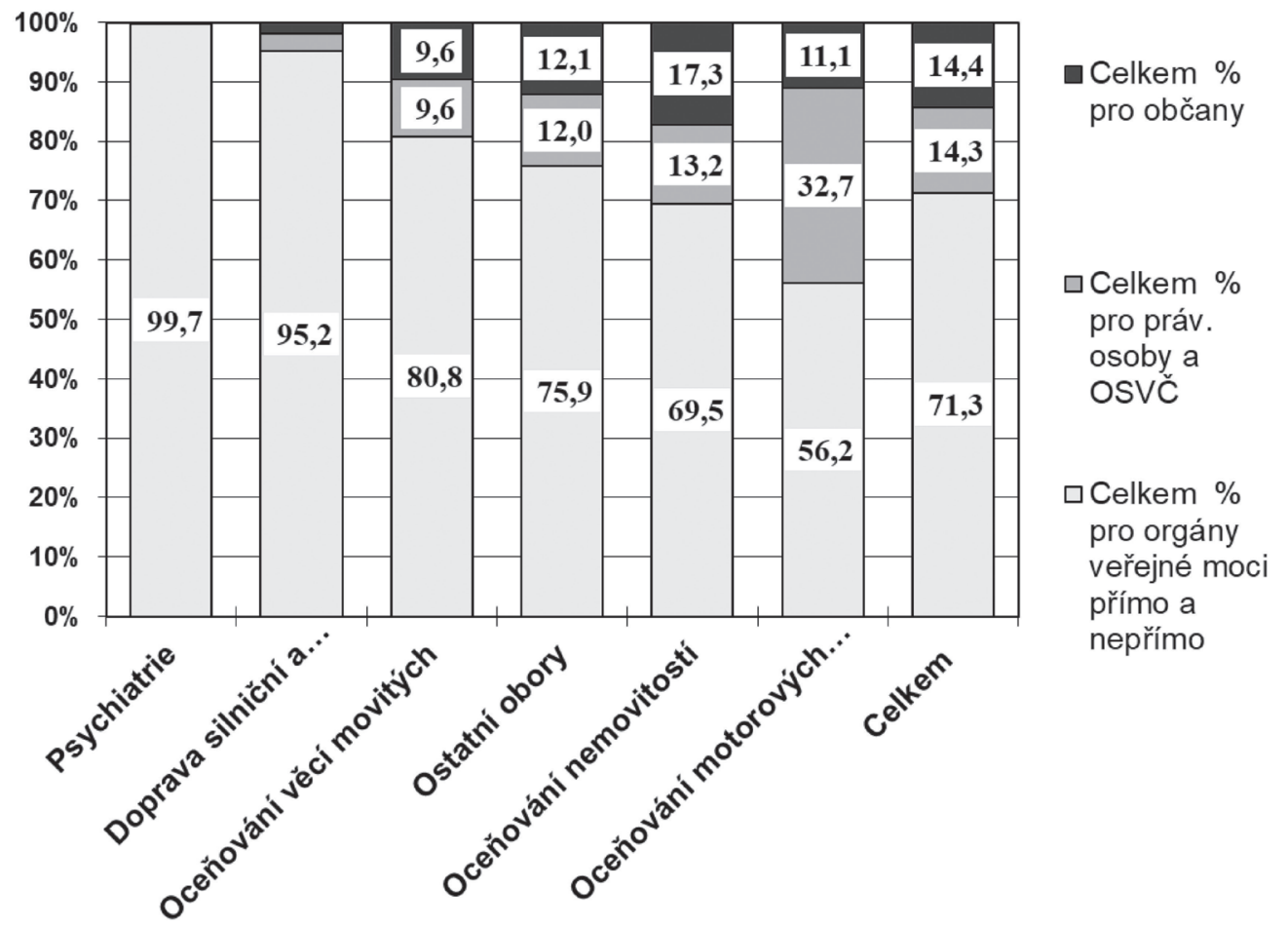

Obr. 4 Počty znaleckých posudků určených pro orgány veřejné moci po přepočtu celkem (1999).

Fig. 4 Number of expert opinions for public authorities after total recalculation (1999).

Tab. 6 Počty znaleckých posudki podle objednateli̊-data MSp z roku 2016.

Tab. 6 Numbers of expert opinions by client-MSP data from 2016.

\begin{tabular}{lcccc}
\hline Objednatelé & Státní orgány & Občané & Ostatní právnické osoby a OSVČ & Celkem \\
\hline Počet znaleckých posudků ČR 2016 & 85130 & 75869 & 90268 & 251267 \\
Procent & $34 \%$ & $30 \%$ & $36 \%$ & $100 \%$ \\
\hline
\end{tabular}




\section{Objednatelé znaleckých posudků dle statistiky \\ Ministerstva spravedlnosti 2016}

\begin{tabular}{|c|}
\hline Ostatní \\
právnické \\
osoby a \\
Osvč \\
$36 \%$ \\
\hline
\end{tabular}

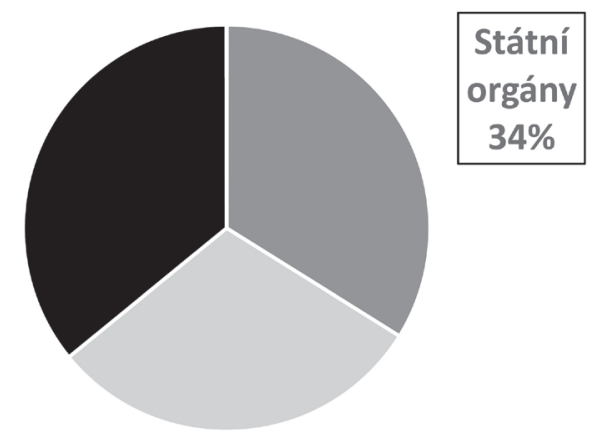

$$
\begin{gathered}
\text { Občané } \\
30 \%
\end{gathered}
$$

Obr. 5 Počty znaleckých posudků podle objednatelů-data MSp z roku 2016.

Fig. 5 Numbers of expert opinions by client-MSP data from 2016.

Tab. 7 Odvody z hrubé mzdy zaměstnance.

Tab. 7 Payments of the gross wage of the employee.

\begin{tabular}{lrr}
\hline Poměrnou část $\mathbf{z}$ hrubé mzdy zaměstnance odvádí: & Zaměstnavatel & Zaměstnanec \\
\hline Odvod na: & $2,30 \%$ & $0,00 \%$ \\
\hline Nemocenské pojištění & $21,50 \%$ & $6,50 \%$ \\
Důchodové pojištění & $1,20 \%$ & $0,00 \%$ \\
Př́spěvek na státní politiku zaměstnanosti & $25,00 \%$ & $6,50 \%$ \\
Celkem & $9,00 \%$ & $4,50 \%$ \\
Zdravotní pojištění & $0,42 \%$ & $0,00 \%$ \\
Zákonné pojištění odpovědnosti za škodu při pracovním úrazu nebo nemoci z povolání, & $\mathbf{3 4 , 4 2 \%}$ & $\mathbf{1 1 , 0 0 \%}$ \\
dle profese - zpravidla & &
\end{tabular}

\section{Rozdělení výnosů zaměstnavatele}

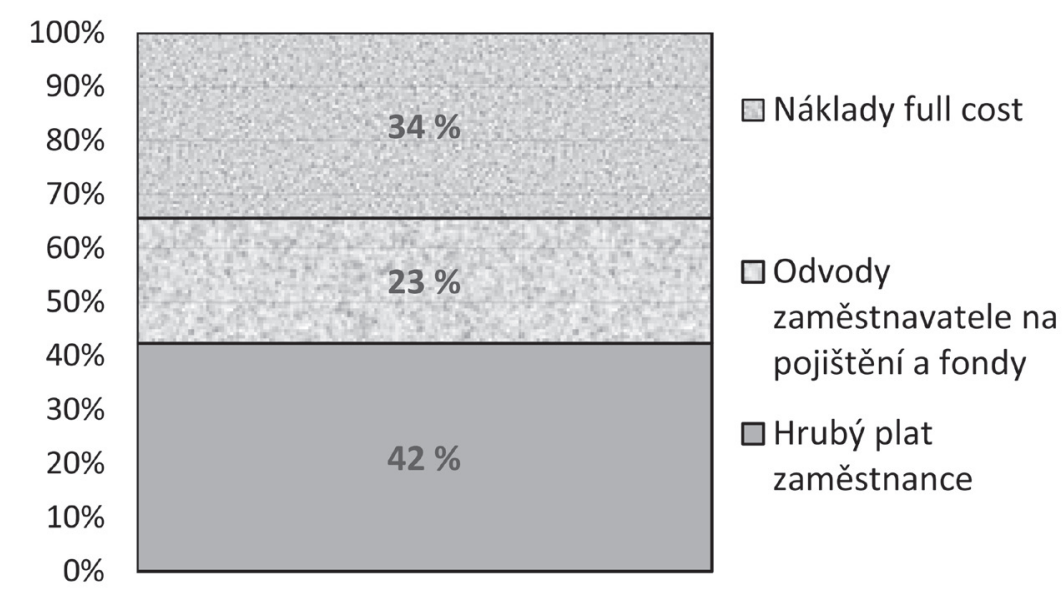

Obr. 6 Rozděleni přijmů u zaměstnavatele (přibližně na V̌́).

Fig. 6 Income distribution at employer (approximately at university). 


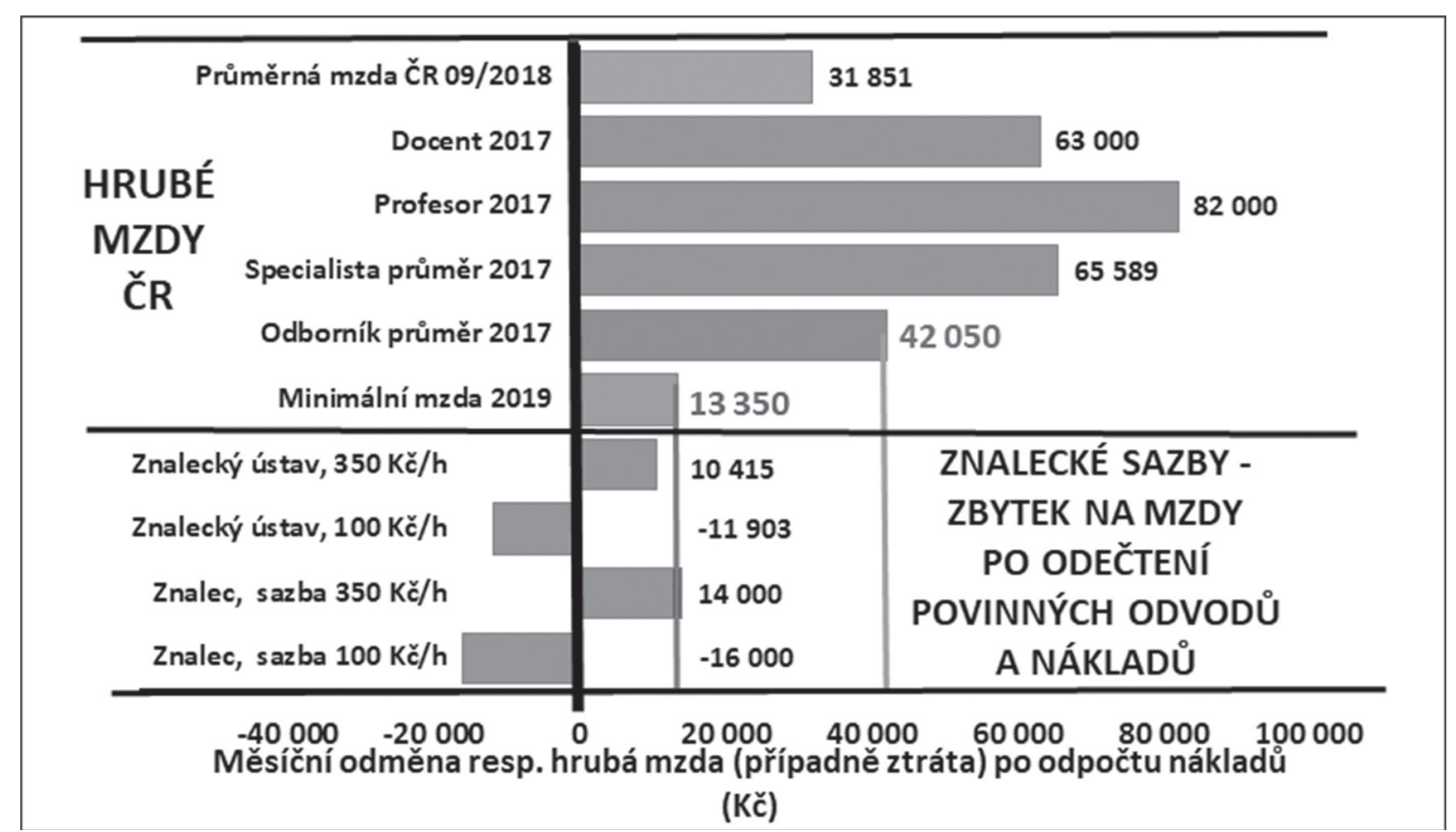

Obr. 7 Porovnání hrubých mezd v ČR se znaleckými sazbami podle vyhlášky č. 37/1967 Sb. po odpočtu zákonných odvodů a nutných nákladů při podáváni znaleckých posudků pro orgány veřejné moci.

Fig. 7 Comparison of gross wages in the Czech Republic with expert rates according to Decree No. 37/1967 Coll. after deduction of statutory deductions and the necessary costs for the submission of expert opinions to public authorities.

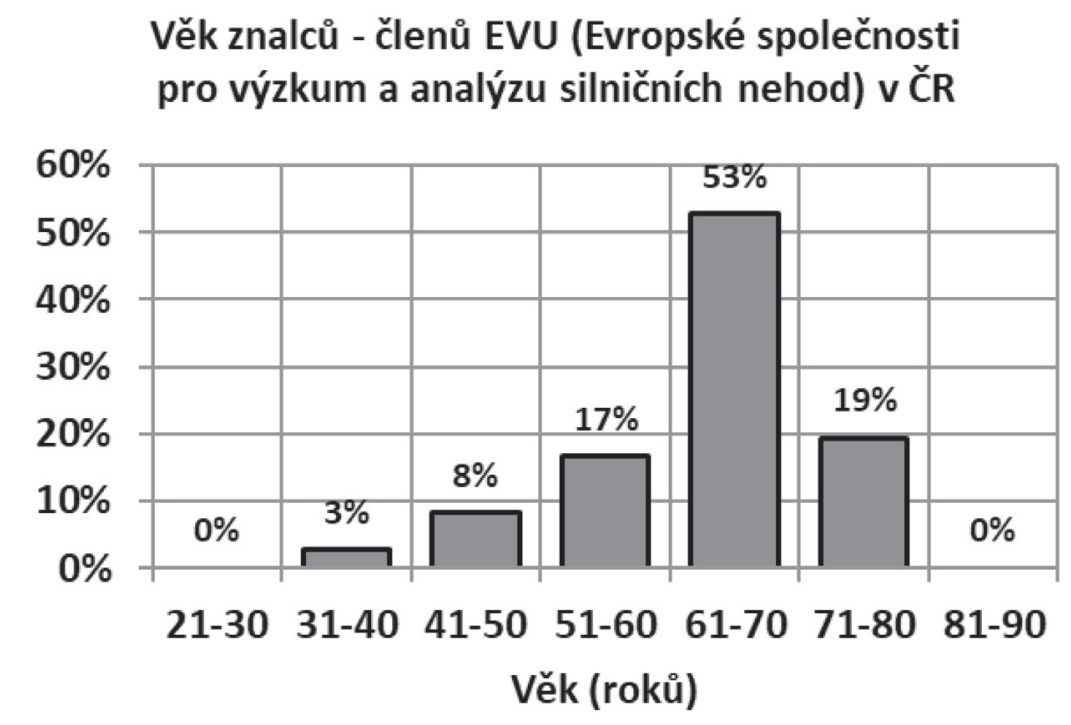

Obr. 8 Věk znalců - členů EVU-NSv ČR.

Fig. 8 Age of Experts - members of EVU in the Czech Republic.

Správná citace:

BRADÁČ, A. Stále tristní stav organizace znalecké činnosti v ČR. Soudní inženýrství, 2018, 29(4), 56-62.

DOI: http://dx.doi.org./10.13164/SI.2018.4.56. ISSN 1211-443X. 